\title{
Dermoid cysts of the floor of mouth: a review
}

\begin{abstract}
Aim: This report aims to evaluate the clinical features, the surgical approaches and the histopathologic outcomes of dermoid cysts in the floor of mouth.

Materials and methods: Data from seven dermoid cyst cases in the floor of mouth between 2003 and 2011 were reviewed.

Results: The mean age of patients were 32, and the male to female ratio was 4:3. The locations of the cysts were sublingual in four patients, submental in one patient, both submental and sublingual in one patient, and submandibular in one patient. Cyst excisions were performed by the extraoral, intraoral, and endoscopic assisted intraoral approaches. The histopathological diagnosis was dermoid cyst for all patients.
\end{abstract}

Conclusion: Dermoid cysts in the floor of mouth are uncommon, and the effective treatment is surgical excision. They should be removed gently and the cosmetic results should also be considered. No excessive surgery is needed.
Volume 2 Issue 3 - 2015

\author{
Mete Iseri,' Selcuk Ucar,' Murat Ozturk,' \\ Safter Arif Ulubil ${ }^{2}$ \\ IDepartment of Otolaryngology, Kocaeli University, Turkey \\ 2Department of Otolaryngology, Acibadem University School of \\ Medicine Fulya Hospital,Turkey
}

Correspondence: Selcuk Ucar, Kocaeli Universitesi Tip Fakultesi Kulak Burun Bogaz Anabilim Dali

4I380, Kocaeli, Turkey, Tel +90 53565007 09, Fax +90 262303

70 03, Email selcukucar26@gmail.com

Received: October 26, 2014 | Published: April 06, 2015

Keywords: floor of mouth, dermoid, cysts, congenital lesions

\section{Introduction}

Dermoid cysts are benign lesions. Primarily seen in the testes and ovaries, $1,6 \%$ of all dermoid cysts occur in the head and neck. ${ }^{1,2}$ Dermoid cysts usually occur in young adults in their $2^{\text {nd }}$ and $3^{\text {rd }}$ decades; however they may also occur in infants. There is no gender discrimination. ${ }^{2}$ Histologically, there are three types of dermoid cysts; epidermoid, dermoid, and teratoid. Usually, the term of dermoid cyst is used for all of these types in clinical practice. Sublingual dermoid cyst cases usually present themselves as a painless swelling in the floor of mouth. In addition, these patients might also experience dysphonia, disarticulation, dysphagia, and dyspnea symptoms. ${ }^{3}$ Submental dermoid cyst cases may present themselves with a swelling that may cause double-chin deformity. Treatment of dermoid cysts is by surgical excision; by extraoral, intraoral or combined approaches. Some authors believe that the treatment consists of excision by intraoral approach in sublingual cysts and extraoral approach in submental cysts. ${ }^{4,5}$ Recurrence is rare when the cyst is completely removed. ${ }^{6}$ In this article, seven cases of floor of mouth dermoid cysts were evaluated the demographic characteristics and surgical approaches.

\section{Materials and methods}

Seven cases of dermoid cysts in the floor of mouth were examined in the Kocaeli University Medical Faculty, Department of Otolaryngology Head and Neck Surgery, during the 8years period between 2003 and 2011. The age, gender, symptoms, physical examination findings, localization, radiologic imaging features of the patients, as well as the surgical approaches used for treatment, follow-up and recurrence in the patients were evaluated. All patients were examined by inspection and bimanual palpation. Magnetic resonance imaging (MRI) was performed on five patients. MRI was not performed to any infant patients. All patients underwent surgery under general anesthesia. According to the size and location of the cyst, the intraoral, the extraoral, the combined intraoral and extraoral, or the assisted endoscopic intraoral approaches could be preferred. Cysts were examined histopathologically for final diagnosis.

\section{Results}

The mean age for the patients was 32 , and the age range was between 1 to 64years. Male to female ratio was 4:3. The initial complaint was painless swelling below the tongue in five patients and below the jaw in two patients. Other symptoms included difficulty in swallowing and speech for three of the patients. Bimanual palpation showed a soft and limited mass in all patients. Locations of the cysts were submental in one patient (14\%), submandibular in one patient (14\%), both sublingual-submental in one patient (14\%), and sublingual in four patients $(57 \%)$ (Figure 1). On MRI, the cysts were observed in the floor of mouth (Figure 2). The cysts were observed hypointense in $\mathrm{T} 1$ weighted images, and hyperintense in $\mathrm{T} 2$ weighted images. The excision operations were performed by extraoral approach in two patients (median submental incision and left submandibular incision), and by intraoral approach in four patients (Figure 3\&4). Demographic data, symptoms, location of the cysts, and the surgical approach used for treatment are given in Table 1. There were no complications in operations. In the histological examination of seven cysts, the cyst lumen was surrounded by numerous stratified keratinized squamous epithelium infiltrated by fibro vascular stroma that were rich in lymphocytes. The histopathologic examination of the cysts identified them as dermoid cyst. No recurrences were observed in any of the patients during the follow-up at 18 months.

\section{Discussion}

Anatomically, the dermoid cysts of the floor of mouth are classified into four types according to their relationship with the muscles in the floor of mouth: Sublingual (above the mylohyoid muscle, 52.5\%), submental (below the mylohyoid muscle, 40.4\%), sublingualsubmental (11.6\%) and lateral (submandibular, $18.2 \%){ }^{7}$ In our cases, the sublingual, sublingual-submental and lateral localizations are consistent with the data in the literature. But submental localization is not consistent. Total excision is the only treatment for dermoid cysts. Different surgical techniques are reported in the literature. These techniques are the extraoral approach, the intraoral approach, 
the combination of these two methods, and the assisted endoscopic intraoral approach. ${ }^{8}$ The intraoral approach is preferred in sublingual located cysts, whereas the extraoral approach is preferred in submental and submandibular located cysts. ${ }^{9}$ However, the extraoral approach may be preferred to or combined with the intraoral approach in larger sublingual cysts and cysts with submental component.

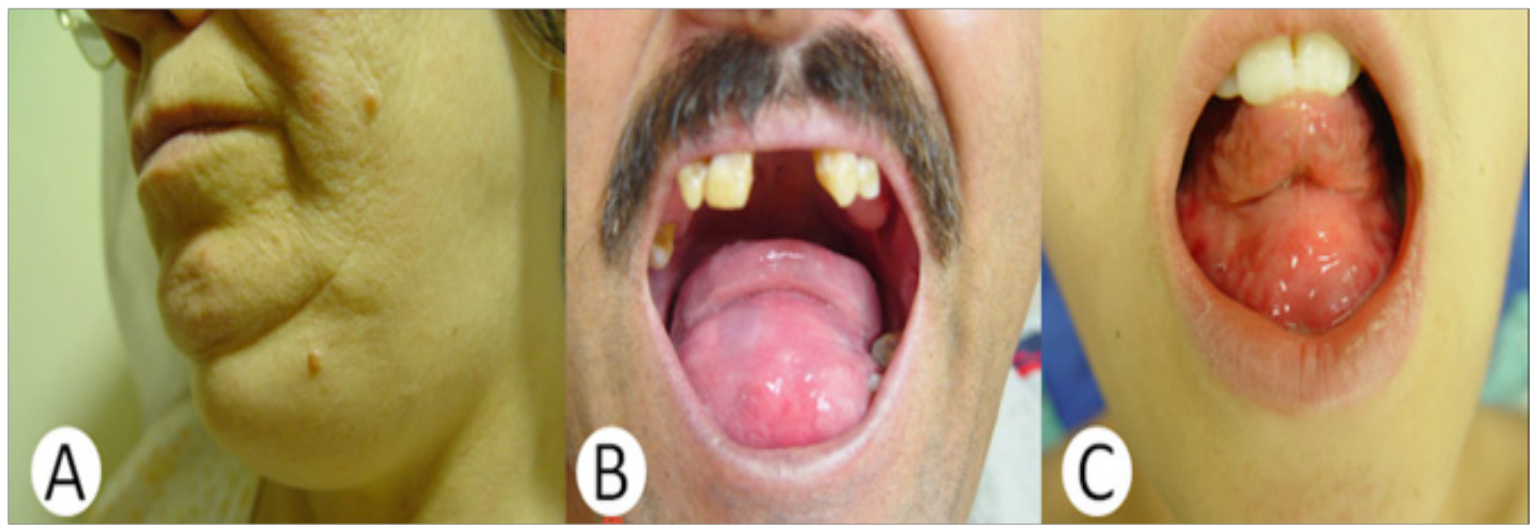

Figure I Clinical photograph of first patient showing submental mass and "double chin" appearance (A), and the second and sixth patients showing sublingual mass $(B, C)$.

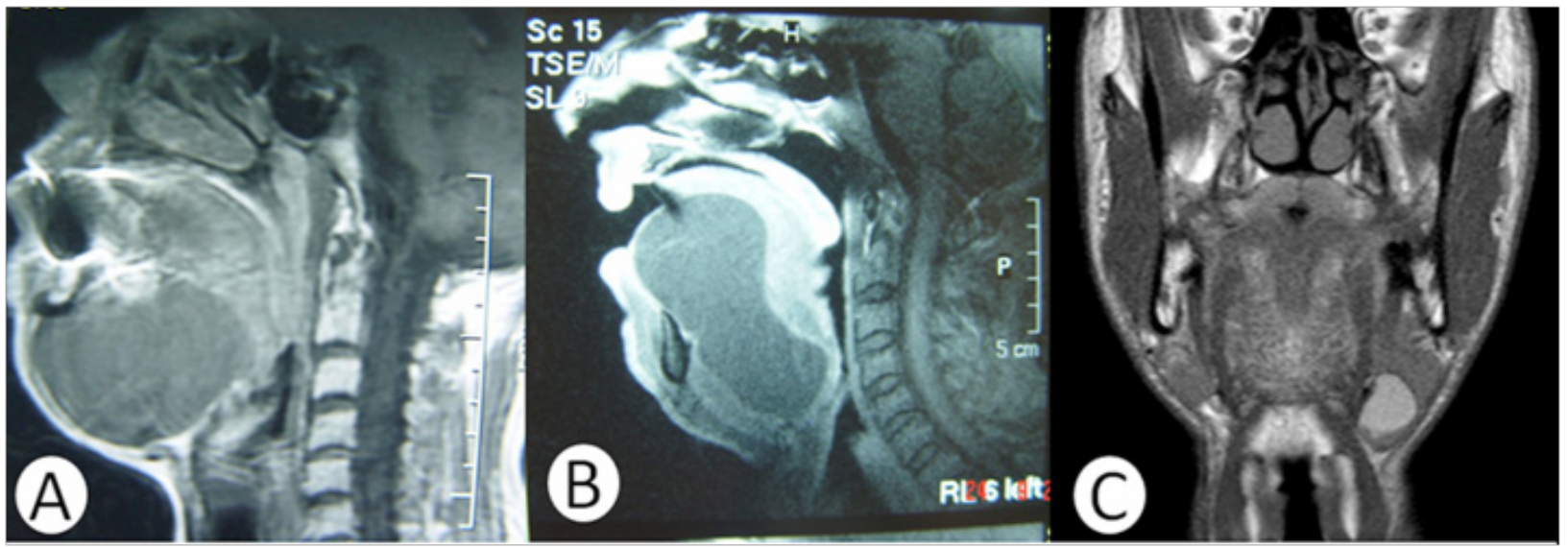

Figure 2 On the MRI, sagittal section with TI weighted of first patient showing the hypointense cyst above the mylohyoid muscle (A). Sagittal section with TI weighted of the second patient showing the hypointense cyst bulged into submental region through the mylohyoid and the geniohyoid muscles (B). Coronal section with TI weighted of fifth patient showing into submandibular region (C).

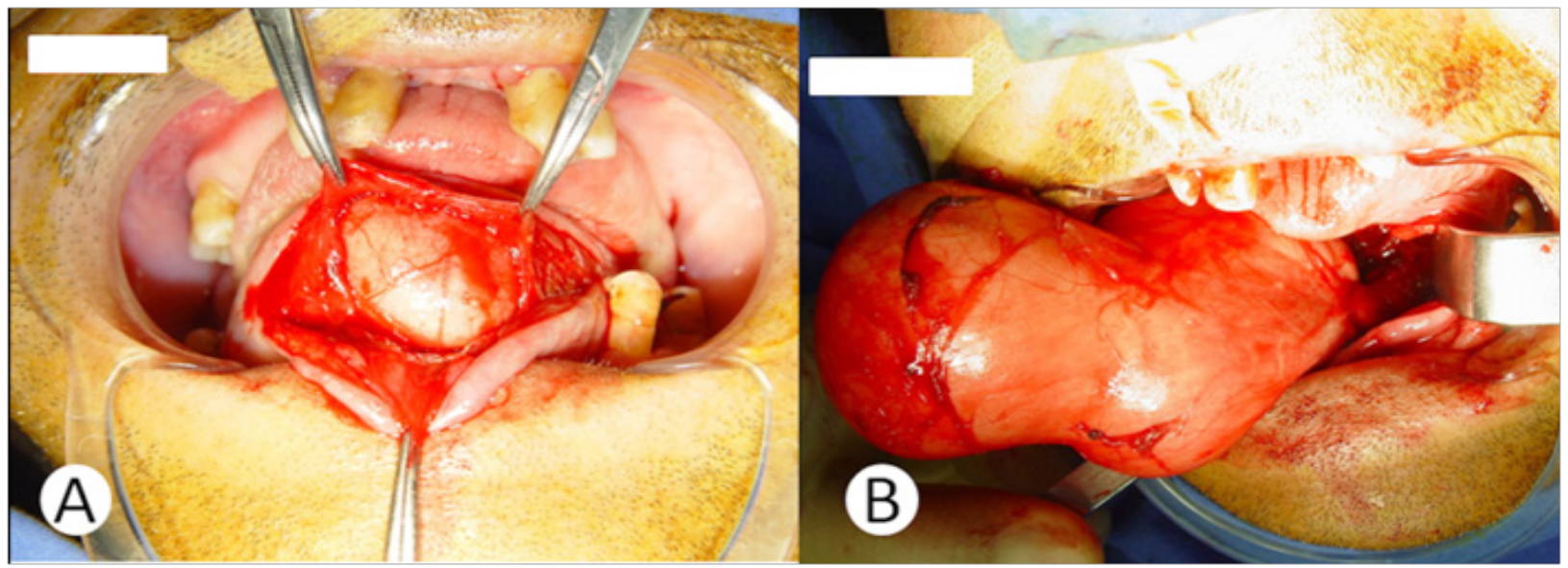

Figure 3 Operative photographs in the second patient, with the incision $(4 \mathrm{~cm})$ made over both the Wharton's duct orifices $(A)$. The cyst was completely removed with blunt dissection without any rupture (B). 


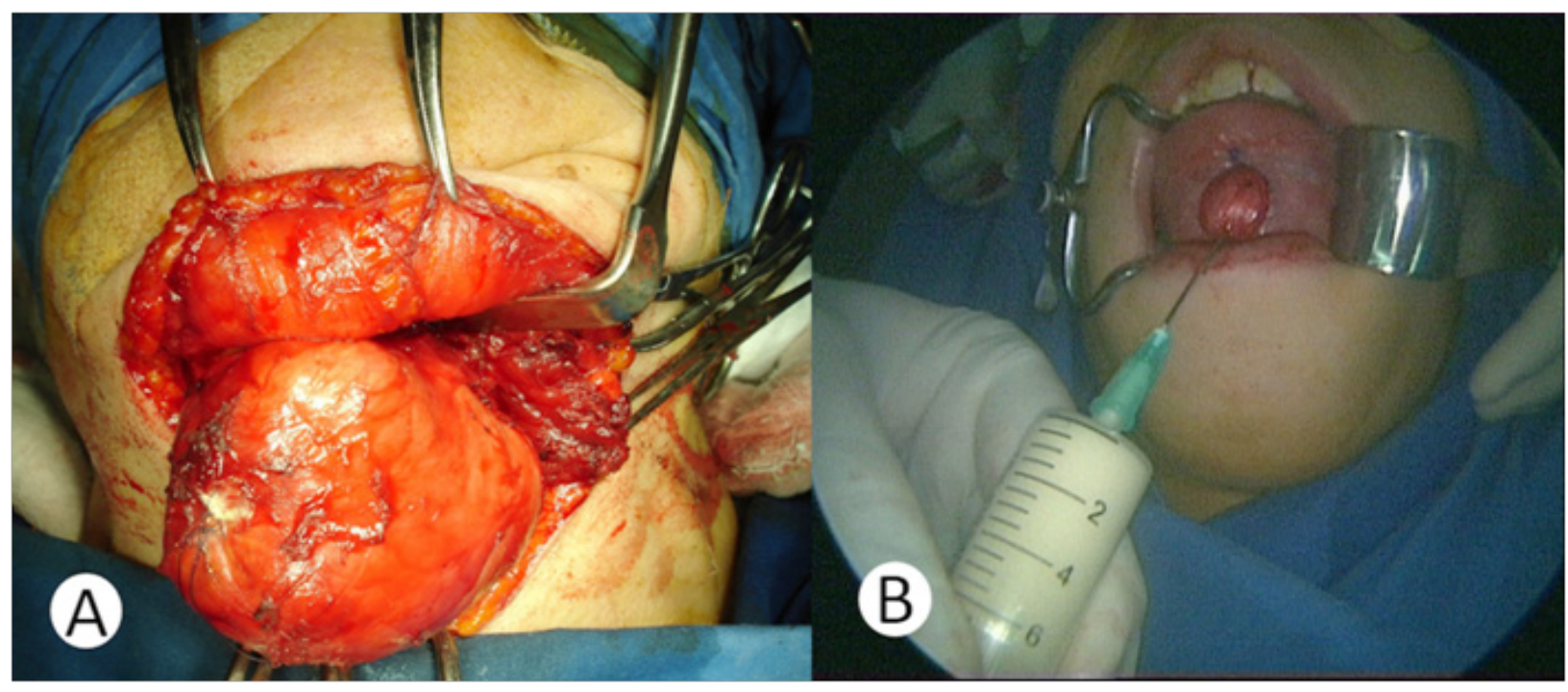

Figure $4 \mathrm{ln}$ the first patient, the cyst was reached with a $7 \mathrm{~cm}$ horizontal skin incision, $4 \mathrm{~cm}$ below the mentum (A). In the sixth patient, a mucosal incision (2, $5 \mathrm{~cm}$ ) was made along the vertical midline in the ventral surface of the tongue without injuring both of the Wharton's duct orifices. The dimension of cyst was reduced by needle aspiration (B).

Table I Summation of demographic data, distribution of sites from and surgical approaches for 7 cases of floor of mouth dermoid cysts

\begin{tabular}{|c|c|c|c|c|c|c|c|}
\hline Cases & Sex & Age & Symptoms & Location & $\begin{array}{l}\text { Size } \\
(\mathrm{cm})\end{array}$ & Surgical Approach & Recurrence \\
\hline I & $\mathrm{F}$ & 60 & $\begin{array}{l}\text { Painless swelling } \\
\text { below the jaw }\end{array}$ & $\begin{array}{l}\text { Median } \\
\text { Submental }\end{array}$ & $7 \times 6 \times 5$ & $\begin{array}{l}\text { Extra oral approach, } 7 \mathrm{~cm} \\
\text { horizontal skin incision } 4 \mathrm{~cm}\end{array}$ & No \\
\hline 2 & $M$ & 47 & $\begin{array}{l}\text { Painless swelling } \\
\text { below the tongue, } \\
\text { difficulty in } \\
\text { swallowing and } \\
\text { speech }\end{array}$ & $\begin{array}{l}\text { Median } \\
\text { Sublingual- } \\
\text { Submental }\end{array}$ & $9 \times 5 \times 4$ & $\begin{array}{l}\text { Intraoral approach, } 4 \mathrm{~cm} \\
\text { horizontal incision, over both the } \\
\text { Wharton's duct orifices. }\end{array}$ & No \\
\hline 3 & $F$ & 64 & $\begin{array}{l}\text { Painless swelling } \\
\text { below tongue, } \\
\text { difficulty in speech }\end{array}$ & $\begin{array}{l}\text { Median } \\
\text { Sublingual }\end{array}$ & $6 \times 4 \times 4$ & $\begin{array}{l}\text { Intraoral approach, } 4 \mathrm{~cm} \text { incision, } \\
\text { over both the Wharton's duct } \\
\text { orifices. }\end{array}$ & No \\
\hline 4 & M & I & $\begin{array}{l}\text { Swelling in below } \\
\text { tongue }\end{array}$ & $\begin{array}{l}\text { Median } \\
\text { Sublingual }\end{array}$ & $2 x|x|$ & $\begin{array}{l}\text { Intraoral approach, } 2 \mathrm{~cm} \text { incision, } \\
\text { over both the Wharton's duct } \\
\text { orifices. }\end{array}$ & No \\
\hline 5 & $M$ & 21 & $\begin{array}{l}\text { Painless swelling } \\
\text { below the jaw }\end{array}$ & $\begin{array}{l}\text { Lateral } \\
\text { Submandibular }\end{array}$ & $3 \times 2 \times 2$ & $\begin{array}{l}\text { Extraoral approach, } 4 \mathrm{~cm} \\
\text { horizontal skin incision } 4 \mathrm{~cm} \\
\text { below the mandible arch }\end{array}$ & No \\
\hline 6 & $\mathrm{~F}$ & 18 & $\begin{array}{l}\text { Painless swelling } \\
\text { below tongue } \\
\text {, difficulty in } \\
\text { swallowing and } \\
\text { speech }\end{array}$ & $\begin{array}{l}\text { Median } \\
\text { Sublingual }\end{array}$ & $6 \times 5 \times 5$ & $\begin{array}{l}\text { Intraoral approach, } 2,5 \mathrm{~cm} \\
\text { incision midline in the ventral } \\
\text { surface of the tongue, between } \\
\text { the Wharton's duct orifices. }\end{array}$ & No \\
\hline 7 & M & 14 & $\begin{array}{l}\text { Swelling in below } \\
\text { tongue }\end{array}$ & $\begin{array}{l}\text { Median } \\
\text { Sublingual }\end{array}$ & $5 \times 4 \times 4$ & $\begin{array}{l}\text { Intraoral approach, } 4 \mathrm{~cm} \text { incision, } \\
\text { over both the Wharton's duct } \\
\text { orifices. }\end{array}$ & No \\
\hline
\end{tabular}

The approach most commonly used in literature is the intraoral approach. ${ }^{7}$ It has been reported that the cosmetic and functional results of the intraoral approach are better. ${ }^{8}$ This approach is usually performed with an incision along the ventral face of tongue, preserving both of the submandibular gland ducts. Some of the cyst content may be aspirated with a needle for safe removal of the larger cysts. In our cases, five patients have been operated by intraoral approach.
The cysts were located sublingually in four of them. In one patient, aspirating the cyst content during the operation, which helped when performing blunt dissection with assisted endoscope, downsized the cyst. Based on the observations we have made with our cases, we have concluded that the intraoral approach is a good and easy technique with better esthetic and functional outcomes. The only complication observed with the intraoral approach reported in the literature is the 
excision of submandibular duct during the operation, which did not occur in our cases. ${ }^{9}$

The extraoral approach is usually performed in cysts that are submental, submandibular, infected or which cause airway obstruction. ${ }^{3}$ In addition, the extra oral approach may be combined with the intraoral approach in giant cysts or in the case of complications encountered during operations. ${ }^{10} \mathrm{We}$ have preferred the extra oral approach in two patients due to the location of the cysts in the submental and submandibular regions. Follow-up for 18 months period revealed that the patients were treated without any complications. The only disadvantage was the incision scar.

\section{Conclusion}

These cysts are very rare, so most otolaryngologists or maxillofacial surgeons will probably see only one case in their lifetime. In order to a guideline for surgeons, we can say that these cysts can be easily dissected from surrounding tissues and excised totally. Therefore, no excessive surgery is required, so, in our opinion, small incisions are adequate, and the surgeon must consider the cosmetic results much more. To get this purpose, the cyst can be aspirated with a needle to downsize it, and then it could be removed via shorter incision on the mucosa or the skin that was done at the beginning of the surgery.

\section{Acknowledgments}

None.

\section{Conflicts of interest}

The authors declare that there are no conflicts of interest.

\section{References}

1. Turetschek K, Hospodka H, Steiner E. Case report: epidermoid cyst of the floor of the mouth: diagnostic imaging by sonography, computed tomography and magnetic resonance imaging. $\mathrm{Br} J$ Radiol. 1995;68(806):205-207.

2. Kandogan T, Koc M, Vardar E, et al. Sublingual epidermoid cyst: a case report. J Med Case Rep. 2007;1:87.

3. MacNeil SD, Moxham JP. Review of floor of mouth dysontogenic cysts. Ann Otol Rhinol Laryngol. 2010;119(3):165-173.

4. Gibson WS Jr, Fenton NA. Congenital subingual dermoid cyst. Arch Otolaryngol. 1982;108(11):745-748.

5. Zachariades N, Skoura-Kafoussia C. A life threatening epidermoid cyst of the floor of the mouth' Report of a case. J Oral Maxillofac Surg. 1990;48(4):400-403.

6. Eken M, Evren C, Sanli A, et al. An alternative surgical approach for sublingual dermoid cysts: a case report. Kulak Burun Bogaz Ihtis Derg. 2007;17(3):176-178.

7. Howell CJ. The sublingual dermoid cyst. Report of five cases and review of the literature. Oral Surg Oral Med Oral Pathol. 1985;59(6):578-580.

8. Longo F, Maremonti P, Mangone GM, et al. Midline (dermoid) cysts of the floor of the mouth: report of 16 cases and review of surgical techniques. Plast Reconstr Surg. 2003;112(6):1560-1565.

9. Akao I, Nobukiyo S, Kobayashi T, et al. A case of large dermoid cyst in the floor of the mouth. Auris Nasus Larynx. 2003;30Suppl:S137-S139.

10. Mathews J, Lancaster J, O'Sullivan G. True lateral dermoid cyst of the floor of the mouth. J Laryngol Otol. 2001;115(4):333-335.

\section{Funding}

None. 